\title{
Genetic mechanisms and correlated risk factors of antimicrobial-resistant ESKAPEE pathogens isolated in a tertiary hospital in Malaysia
}

Soo Tein Ngoi ${ }^{1}$, Chun Wie Chong ${ }^{2}$, Sasheela Sri La Sri Ponnampalavanar ${ }^{3}$, Soo Nee Tang ${ }^{1}$, Nuryana Idris ${ }^{1}$, Kartini Abdul Jabar ${ }^{1}$, Michael J. Gregory ${ }^{4}$, Tupur Husain ${ }^{4}$ and Cindy Shuan Ju Teh ${ }^{1^{*}}$

\begin{abstract}
Background: Knowledge on the epidemiology, genotypic and phenotypic features of antimicrobial-resistant (AMR) ESKAPEE pathogens (Enterococcus faecium, Staphylococcus aureus, Klebsiella pneumoniae, Acinetobacter baumannii, Pseudomonas aeruginosa, Enterobacter spp., and Escherichia coli) and their association with hospital-acquired infections (HAls) are limited in Malaysia. Therefore, we evaluated the AMR features and resistance mechanisms of the ESKAPEE pathogens collected in a tertiary hospital located in the capital of Malaysia.
\end{abstract}

Methods: A total of 378 AMR-ESKAPEE strains were obtained based on convenience sampling over a nine-month study period (2019-2020). All strains were subjected to disk diffusion and broth microdilution assays to determine the antimicrobial susceptibility profiles. Polymerase chain reaction (PCR) and DNA sequence analyses were performed to determine the AMR genes profiles of the non-susceptible strains. Chi-square test and logistic regression analyses were used to correlate the AMR profiles and clinical data to determine the risk factors associated with HAls.

Results: High rates of multidrug resistance (MDR) were observed in A. baumannii, K. pneumoniae, E. coli, and S. aureus (69-89\%). All organisms except E. coli were frequently associated with HAls (61-94\%). Non-susceptibility to the last-resort drugs vancomycin (in Enterococcus spp. and S. aureus), carbapenems (in A. baumannii, P. aeruginosa, and Enterobacteriaceae), and colistin (in Enterobacteriaceae) were observed. Both A. baumannii and K. pneumoniae harbored a wide array of extended-spectrum $\beta$-lactamase genes $\left(b / a_{T E M}, b / a_{S H V}, b / a_{C T X-M}, b / a_{O X A}\right)$. Metallo- $\beta$-lactamase genes ( $\left.b / a_{\mathrm{VEB}}, b / a_{\mathrm{VIM}}, b / a_{\mathrm{NDM}}\right)$ were detected in carbapenem-resistant strains, at a higher frequency compared to other local reports. We detected two novel mutations in the quinolone-resistant determining region of the gyrA in fluoroquinolone-resistant E. coli (Leu-102-Ala; Gly-105-Val). Microbial resistance to ampicillin, methicillin, and cephalosporins was identified as important risk factors associated with HAls in the hospital.

Conclusion: Overall, our findings may provide valuable insight into the microbial resistance pattern and the risk factors of ESKAPEE-associated HAls in a tertiary hospital located in central Peninsular Malaysia. The data obtained in this study may contribute to informing better hospital infection control in this region.

*Correspondence: cindysjteh@um.edu.my

${ }^{1}$ Department of Medical Microbiology, Faculty of Medicine, Universiti

Malaya, 50603 Kuala Lumpur, Malaysia

Full list of author information is available at the end of the article permits use, sharing, adaptation, distribution and reproduction in any medium or format, as long as you give appropriate credit to the original author(s) and the source, provide a link to the Creative Commons licence, and indicate if changes were made. The images or other third party material in this article are included in the article's Creative Commons licence, unless indicated otherwise in a credit line to the material. If material is not included in the article's Creative Commons licence and your intended use is not permitted by statutory regulation or exceeds the permitted use, you will need to obtain permission directly from the copyright holder. To view a copy of this licence, visit http://creativecommons.org/licenses/by/4.0/. The Creative Commons Public Domain Dedication waiver (http://creativeco mmons.org/publicdomain/zero/1.0/) applies to the data made available in this article, unless otherwise stated in a credit line to the data. 
Keywords: AMR-conferring genes, Minimum inhibitory concentration, Molecular epidemiology, Multidrug-resistant organisms, Nosocomial infections, Risk factors analysis

\section{Background}

The antimicrobial resistance (AMR) phenomenon among clinically important human pathogens remains a major threat to public health worldwide. The global emergence and spread of AMR organisms have been documented and are often associated with increasing incidences of treatment failure and adverse clinical outcomes [1]. The World Health Organization (WHO) reported a significant increase in the mortality rates and intensive care unit (ICU) admission rates of patients infected by AMR organisms, based on a systematic review on drug-resistant Escherichia coli, Klebsiella pneumoniae, and Staphylococcus aureus [1]. The emergence of bacteria that are resistant to multiple antimicrobial agents has gained notoriety as an important global public health issue [2]. Infections caused by multidrug-resistant organisms (MDROs) are reported everywhere in the world, compromising our ability to treat infectious diseases. Due to the impact of MDROs on public health, WHO released a list of the world's most dangerous superbugs in February 2017 [3]. The ESKAPEE pathogens (Enterococcus faecium, Staphylococcus aureus, Klebsiella pneumoniae, Acinetobacter baumannii, Pseudomonas aeruginosa, Enterobacter species, and Escherichia coli) are listed as organisms of critical importance due to their MDR nature and increased resistance to last-resort drugs, consequently requiring urgent development of new antibiotics [3].

Antimicrobial resistance occurs naturally over time through genetic mutations and exchanges, although these genetic events usually take place at low frequencies [4]. The process of AMR emergence, dissemination, and persistence among bacteria, however, has been accelerated due to the overuse or misuse of antimicrobials in the hospital settings, livestock farming, and aquaculture industry [5]. The development of acquired resistance in commensals or previously non-resistant bacteria can be attributed to chromosomal mutations or acquisition of external genetic determinants of resistance via horizontal gene transfer (HGT) within a reservoir [6]. The microbiomes of humans and animals, as well as environmental sources, frequently serve as the reservoirs for HGT among the bacterial cells. Escherichia coli, Klebsiella pneumoniae, Enterobacter spp., and Enterococcus spp. are intestinal commensals that were once considered relatively harmless, have now evolved into MDROs that are responsible for various healthcare-associated infections (HCAIs) [7, 8]. In addition, the increase in the number of infections caused by other MDR opportunistic pathogens, such as Staphylococcus aureus, Acinetobacter baumannii, and Pseudomonas aeruginosa in hospitals has also been widely observed in Asia [9].

HCAI is defined as an infection acquired by a patient under medical care in the hospital or other healthcare facility, which was absent at the time of admission [10]. HCAI represents the most frequent adverse event in healthcare delivery worldwide. In Malaysia, the hospital-wide prevalence of HCAIs is rated at $14 \%$, two-fold higher than neighboring countries Thailand (6.5\%) and Indonesia (7.1\%) [10]. HCAIs often pose a significant threat to hospitalized individuals and further complicate infection management in healthcare settings, particularly in critical care units where patients have an increased risk of infection due to their underlying diseases or comorbidity predispositions, impaired immunity, and exposure to multiple invasive devices such as catheters [11]. HCAIs caused by MDROs are more difficult to treat and result in a significant increase in mortality rates and financial losses for the health system in a country [12]. The common practice of initial broad-spectrum antibiotics treatment often selects for MDROs persistence in the healthcare settings, leading to the development of severe HCAIs in institutionalized patients [11].

Effective infection prevention and control measures are critical in limiting the dissemination of drug-resistant bacteria in healthcare settings, and thus preventing HCAI outbreaks. However, a lack of adequate systems and research support has hampered the ability in many healthcare settings to effectively implement comprehensive infection control strategies [13]. In order to establish a monitoring pathway for bacterial transmissions and infections, information such as the resistance mechanisms should be linked with the strains phenotypic profiles as well as the host characteristics. Molecular surveillance, and in particular the surveillance of resistance genes detection, is necessary for hospital infection control, through the detection of emerging pathogens and monitoring of AMR trends for better patient management. Further, understanding of the AMR mechanisms would also aid in the prediction of underlying or unknown resistance mechanisms, susceptibility to other antimicrobial agents, and would contribute to the development of new drug or therapeutics to combat MDROs infection [14].

In this study, we aimed to investigate the genotypic and phenotypic features of drug-resistant ESKAPEE 
pathogens in a tertiary hospital to identify the AMR trends and molecular epidemiology of the organisms throughout the study period. Microbiological data were associated with host characteristics and clinical factors to provide a comprehensive insight into rational treatment strategies and infection control measures in Malaysian hospitals.

\section{Materials and methods}

\section{Bacterial strains collection and identification}

A total of 378 clinical, non-repeat bacterial strains were prospectively collected from the diagnostic laboratory of the University of Malaya Medical Centre (UMMC), a tertiary hospital located in Kuala Lumpur Malaysia, within a nine-month study period (October 2019-July 2020). The ESKAPEE pathogens investigated in this study include Enterococcus spp., Staphylococcus aureus (S. aureus), Klebsiella pneumoniae (K. pneumoniae), Acinetobacter baumannii (A. baumannii), Pseudomonas aeruginosa (P. aeruginosa), Enterobacter spp., and Escherichia coli (E. coli). All bacterial strains $(\mathrm{n}=54$ per species) were first identified based on conventional culture method and automated microbial identification VITEK ${ }^{\circledR} 2$ system (bioMérieux, Marcy-l'Étoile, France), during routine microbiological investigations at the hospital's diagnostic laboratory. The identity of the bacterial strains was further confirmed by polymerase chain reaction (PCR) detection of genus/species-specific genes from the boiled lysate of bacterial cells, prior to further phenotypic and genotypic analyses. The PCR primers and reaction mixture compositions were adapted from published studies (Additional file 1: Table S1). Minor modifications were made to the thermal-cycling parameters (Additional file 1: Table S1). Agarose gel electrophoresis was used to visualize the presence of amplicons in the PCR products. The agarose gel $\left(1 \%\right.$ w/v) was stained with GelRed ${ }^{\circledR}$ Nucleic Acid Gel Stain (Biotium, Fremont, USA) and viewed using a blue light transilluminator.

\section{Antimicrobial susceptibility testing of the bacterial strains}

The antimicrobial susceptibility profiles of the confirmed bacterial strains were determined by the hospital's diagnostic laboratory using VITEK ${ }^{\circledR} 2$ system. All ESKAPEE strains selected for further investigation were resistant to at least one antibiotic based on VITEK ${ }^{\circledR} 2$ analyses. The antimicrobial susceptibility phenotypes of the bacterial strains against selected agents were further confirmed via the Kirby-Bauer disk diffusion method based on Clinical and Laboratory Standards Institute (CLSI) recommendations [15]. The zones of inhibition for the tested antimicrobial agents were interpreted according to CLSI guidelines. Bacterial strains showing reduced susceptibility or resistant to selected antimicrobial agents of interest were further subjected to minimum inhibitory concentration (MIC) testing using broth microdilution method based on CLSI guidelines. The median MIC value is indicated as $\mathrm{MIC}_{50}$. The MIC required to inhibit the growth of $90 \%$ of the bacterial strains is indicated as $\mathrm{MIC}_{90}$.

\section{Characterization of the antimicrobial resistance gene profiles of the ESKAPEE pathogens}

Based on the antimicrobial susceptibility test results, all ESKAPEE strains that were non-susceptible to the tested antimicrobial agents were further subjected to molecular analysis to determine the AMR gene profiles. PCR assays were conducted using established primer sequences adapted from published studies (Additional file 1: Table S2). AMR genes encoding for vancomycin resistance (van $\mathrm{AB})$, aminoglycoside-modifying enzymes (aac, aad, ant, and aph variants), methicillin resistance (mecA), erythromycin resistance (erm $\mathrm{ABC}$ ), quinolone/ fluoroquinolone resistance (gyr AB, parCE, and qnr $\mathrm{ABC}$ ), and beta-lactamases (TEM, SHV, CTX-M, OXA, VIM, IMP, NDM, KPC, PER, VEB, and SIM) were selectively screened based on bacterial species. The PCR conditions used in this study were optimized for a lower reaction volume. All targeted genes were individually amplified in a $25 \mu \mathrm{L}$ reaction mixture consisting of $1 \times$ PCR buffer, $1.5 \mathrm{mM} \mathrm{MgCl}, 100 \mu \mathrm{M}$ deoxynucleoside triphosphates (dNTPs), 1 U Taq polymerase (Promega, Madison, USA), and approximately $150 \mathrm{ng}$ of DNA template obtained from the boiled lysate of bacterial cell suspension. Working concentrations of the primers for the targeted genes or genetic regions are shown in Additional file 1: Table S2. PCR thermal cycling conditions for all reactions included an initial denaturation at $95^{\circ} \mathrm{C}(5 \mathrm{~min})$, followed by 30 cycles of denaturation at $94{ }^{\circ} \mathrm{C}(40 \mathrm{~s})$, annealing at $48-68{ }^{\circ} \mathrm{C}$ (40 s) (Additional file 1: Table S2), and extension at $72{ }^{\circ} \mathrm{C}(1 \mathrm{~min})$. The PCR cycles ended with a final extension at $72{ }^{\circ} \mathrm{C}$ for $7 \mathrm{~min}$. Agarose gel electrophoresis was used to visualize the presence of a PCR amplicon. For the identification of gene variants, the PCR products were purified using MEGAquick-spin ${ }^{\text {TM }}$ Plus Total Fragment DNA Purification Kit (iNtRON Biotechnology, Gyeonggi-do, Korea). Next, the purified amplicons were subjected to DNA sequencing by a commercial sequencing service provider (First BASE Laboratories, Petaling Jaya, Malaysia), and the sequences obtained were analyzed using National Center for Biotechnology Information (NCBI) Basic Local Alignment Search Tool (BLAST) to identify the gene variant. In order to determine the position of base substitutions in the gyrase ( $g y r \mathrm{AB})$ and topoisomerase IV (parCE) genes, the amplicon sequences were aligned and compared with the reference gene sequences in E. coli strain ATCC 25922 (NCBI GenBank 
accession number CP037449) by using the Molecular Evolutionary Genetics Analysis (MEGA) X software [16].

\section{Patient data collection and correlation analysis}

Relevant patient and clinical data including basic demographic information (age, gender, and ethnicity), admission date, bacterial isolation date, and type of specimen source were extracted from the clinical database. The mode of acquisition of infection, i.e. community-acquired (CA) or hospital-acquired (HA), was inferred based on the patient's admission date and bacterial isolation date. Infection is determined as HA if the patient developed signs of infection and a positive bacterial culture was obtained at $48 \mathrm{~h}$ or more post-admission. Descriptive statistics are expressed as percentage unless otherwise stated. Categorical variables were expressed as percentages and compared using the Chi-square test. Variables with a univariate test value of less than 0.1 (p-value) were included in a multivariate analysis using a logistic regression model. Odds ratios (OR) and 95\% confidence intervals $(\mathrm{CI})$ were calculated.

\section{Results:}

The clinical features of all 378 ESKAPEE strains collected during study period are summarized in Table 1 . The AMR rates and MIC ranges of selected antimicrobial agents, as well as the prevalence of AMR genes for each bacterial species, are individually reported in this section. The detailed strain profiles for each of the ESKAPEE organisms are provided in Additional file 1: Table S3-S9.

\section{Enterococcus spp.}

Among the 54 Enterococcus spp. strains examined in this study, E. faecalis (43\%) and E. faecium (41\%) made up the major portion of the strains collection. Other Enterococcus species obtained from the clinical specimens include avium $(\mathrm{n}=1)$, gallinarum $(\mathrm{n}=1)$, hirae $(\mathrm{n}=2)$, and raffinosus $(\mathrm{n}=3)$. Majority of the

Table 1 Summary of the clinical features of ESKAPEE strains $(n=378)$ examined in this study

\begin{tabular}{|c|c|c|c|c|c|c|c|}
\hline & $\begin{array}{l}\text { Enterococcus } \\
\text { spp. }(\mathrm{n}=54)\end{array}$ & S. aureus $(\mathrm{n}=54)$ & $\begin{array}{l}\text { K. } \\
\text { pneumoniae } \\
(n=54)\end{array}$ & $\begin{array}{l}\text { A. baumannii } \\
(n=54)\end{array}$ & $\begin{array}{l}P . \\
\text { aeruginosa } \\
(n=54)\end{array}$ & $\begin{array}{l}\text { Enterobacter } \\
\text { spp. }(\mathrm{n}=54)\end{array}$ & $\begin{array}{l}\text { E. coli } \\
(n=54)\end{array}$ \\
\hline & (n) (\%) & (n) (\%) & (n) (\%) & (n) (\%) & (n) (\%) & (n) (\%) & (n) (\%) \\
\hline \multicolumn{8}{|l|}{ Age range } \\
\hline$<18$ years & $4(7)$ & $3(6)$ & $5(9)$ & $1(2)$ & $8(15)$ & $5(9)$ & $4(7)$ \\
\hline $18-59$ years & $24(45)$ & $20(37)$ & $18(33)$ & $25(46)$ & $18(33)$ & $20(37)$ & $17(32)$ \\
\hline$\geq 60$ years & $26(48)$ & $31(57)$ & $31(58)$ & $28(52)$ & $28(52)$ & $19(35)$ & $33(61)$ \\
\hline \multicolumn{8}{|l|}{ Gender } \\
\hline Male & $33(61)$ & $31(57)$ & $35(65)$ & 37 (69) & $30(56)$ & $36(67)$ & $26(48)$ \\
\hline Female & $21(39)$ & $23(43)$ & $19(35)$ & $17(31)$ & $24(44)$ & $18(33)$ & $28(52)$ \\
\hline \multicolumn{8}{|l|}{ Ethnicity } \\
\hline Malay & $18(33)$ & $21(39)$ & $16(30)$ & $14(26)$ & $20(37)$ & 19 (35) & $14(26)$ \\
\hline Chinese & $17(31)$ & $17(31)$ & $23(43)$ & $15(28)$ & $21(39)$ & $18(33)$ & $26(48)$ \\
\hline Indian & $16(30)$ & $16(30)$ & $11(20)$ & $22(40)$ & $12(22)$ & $15(28)$ & $11(20)$ \\
\hline Others & $3(6)$ & $0(0)$ & $4(7)$ & $3(6)$ & $1(2)$ & $2(4)$ & $3(6)$ \\
\hline \multicolumn{8}{|l|}{ Mode of acquisition } \\
\hline Hospital acquired & $36(67)$ & $35(65)$ & $38(72)$ & $51(94)$ & $34(63)$ & $33(61)$ & $25(46)$ \\
\hline Community acquired & $18(33)$ & $19(35)$ & $15(28)$ & $3(6)$ & $20(37)$ & $21(39)$ & $29(54)$ \\
\hline \multicolumn{8}{|l|}{ Specimen source } \\
\hline Respiratory sites & $0(0)$ & $12(22)$ & $18(33)$ & $37(69)$ & $30(56)$ & $26(48)$ & $7(13)$ \\
\hline $\begin{array}{l}\text { Body fluids (blood, tissue } \\
\text { fluids, urine, etc.) }\end{array}$ & $37(69)$ & $20(37)$ & $27(50)$ & $7(13)$ & $17(31)$ & $6(11)$ & $32(59)$ \\
\hline Tissues and swabs & $17(31)$ & $22(41)$ & $9(17)$ & $10(18)$ & $7(13)$ & $22(41)$ & $15(28)$ \\
\hline \multicolumn{8}{|l|}{ Hospital admission record } \\
\hline Critical/Intensive care units & $7(13)$ & $1(2)$ & $10(19)$ & $27(50)$ & $6(11)$ & $8(15)$ & $6(11)$ \\
\hline Medical wards & $44(81)$ & $51(94)$ & $41(77)$ & $27(50)$ & $41(76)$ & $40(74)$ & $43(80)$ \\
\hline Outpatient & $3(6)$ & $2(4)$ & $2(4)$ & $0(0)$ & $7(13)$ & $6(11)$ & $5(9)$ \\
\hline \multicolumn{8}{|l|}{ Multidrug resistance } \\
\hline MDR & $2(4)$ & $37(69)$ & $47(87)$ & $48(89)$ & $11(20)$ & $6(11)$ & $37(69)$ \\
\hline Non-MDR & $52(96)$ & $17(31)$ & $7(13)$ & $6(11)$ & $43(80)$ & $48(89)$ & $17(31)$ \\
\hline
\end{tabular}


Enterococcus spp. strains were associated with HA infections (67\%) and 19\% of which occurred in patients admitted to the intensive care units (ICUs). A considerable subset of the Enterococcus spp. (39\%) were highly resistant to ampicillin with MIC values ranging from $64 \mu \mathrm{g} / \mathrm{mL}$ to $256 \mu \mathrm{g} / \mathrm{mL}$ and above $\left(\mathrm{MIC}_{50}=256 \mu \mathrm{g} /\right.$ $\mathrm{mL})$. The majority of the strains $(87 \%)$ were susceptible to vancomycin. Six vancomycin-resistant enterococci (VRE) strains were identified in this study (Table 2). The majority of the VRE (67\%) showed a low level of resistance to vancomycin (MIC $\leq 32 \mu \mathrm{g} / \mathrm{mL}$ ). Most of the VRE (83\%) were isolated from blood and bone specimens of the patients, indicating the invasive nature of the organisms. Half of the VRE were associated with HA infections. All Enterococcus strains exhibited a streptomycin-resistant phenotype with a high level of resistance $\left(\mathrm{MIC}_{50}=128 \mu \mathrm{g} / \mathrm{mL}\right)$. High-level aminoglycoside resistance (HLAR) was indicated in $39 \%$ of the Enterococcus spp., whereby the strains endured a high concentration of streptomycin at $1000 \mu \mathrm{g} / \mathrm{mL}$ in the growth medium.

The Enterococcus spp. strains were screened for the presence of six aminoglycoside resistance-conferring gene variants in this study. The most prevalent aminoglycoside-modifying enzyme (AME) gene was $\operatorname{ant}\left(4^{\prime}\right)-I a(22 \%)$, followed by aph(2")-Ic (15\%), and $a a c\left(6^{\prime}\right)-I e-a p h\left(2^{\prime \prime}\right)-I a(7 \%)$. The AME genes $a p h\left(2^{\prime \prime}\right)-I b$, $a p h\left(2^{\prime \prime}\right)-I d$, and $a p h\left(3^{\prime}\right)-I I I a$ were absent among the strains. All except one VRE strains harbored the vanB gene (Table 2). Two HA-VRE strains, one obtained from a swab sample and one from a blood sample, carried both $\operatorname{van} \mathrm{A}$ and $\operatorname{van} \mathrm{B}$ genes. Interestingly, the presence of both van genes in the VRE strains does not necessarily indicate a high level of vancomycin resistance. One of the VRE strains harboring both van genes was highly resistant to vancomycin (MIC $\geq 256 \mu \mathrm{g} /$ $\mathrm{mL}$ ), while the other showed only low-level resistance $(\mathrm{MIC}=32 \mu \mathrm{g} / \mathrm{mL})$. One E. faecalis strain with reduced susceptibility to vancomycin $(\mathrm{MIC}=16 \mu \mathrm{g} / \mathrm{mL})$ harbored a $\operatorname{van} \mathrm{B}$ gene.

\section{Staphylococcus aureus}

The $S$. aureus strains examined in this study comprised of majority methicillin-resistant S. aureus (MRSA) (85\%) and only eight methicillin-susceptible $S$. aureus (MSSA) (15\%). The majority of S. aureus (65\%) caused HA infections. The MSSA strains were found to be more commonly associated with CA infections compared to their methicillin-resistant counterpart. The $S$. aureus was mostly MDR (69\%). The MDR phenotype was especially common among the MRSA (80\%), while all MSSA strains remained susceptible to most of the antimicrobial agents tested. The $S$. aureus strains were largely resistant to penicillin $(98 \%)$. All strains were susceptible to linezolid, rifampicin, and vancomycin. The MIC values of vancomycin ranged from less than $0.5 \mu \mathrm{g} / \mathrm{mL}$ to $1 \mu \mathrm{g} / \mathrm{mL}$ $\left(\mathrm{MIC}_{50 / 90}=0.5 / 1 \mu \mathrm{g} / \mathrm{mL}\right)$.

The identity of the MRSA strains was confirmed by both oxacillin and cefoxitin (agent for the surrogate test) resistance. All MRSA strains showed a moderate or high level of resistance to oxacillin, with MIC values ranging from $16 \mu \mathrm{g} / \mathrm{mL}$ to $256 \mu \mathrm{g} / \mathrm{mL}$ and above $\left(\mathrm{MIC}_{50}=256 \mu \mathrm{g} /\right.$ $\mathrm{mL}$ ). The presence of the mecA gene in all MRSA strains was confirmed by molecular detection of the gene using the PCR method. The majority of the S. aureus strains (69\%) were identified as clindamycin-resistant, although most of which were considered inducible clindamycin resistance (73\%) as indicated by erythromycin resistance. The erythromycin resistance-conferring gene, ermC, was identified in all $S$. aureus strains that exhibited erythromycin-resistant phenotype $(\mathrm{n}=37)$.

\section{Acinetobacter baumannii}

The $A$. baumannii strains examined in this study were mostly associated with HA infections (94\%). Half of the A. baumannii strains were isolated from ICUs, including general, cardiac, and neonatal ICUs. The majority of

Table 2 Enterococcus strains with resistant or reduced susceptibility phenotypes to vancomycin

\begin{tabular}{|c|c|c|c|c|c|c|}
\hline \multirow[t]{2}{*}{ Study code } & \multirow[t]{2}{*}{ Enterococcus species } & \multirow{2}{*}{$\begin{array}{l}\text { Type of } \\
\text { infection }\end{array}$} & \multirow[t]{2}{*}{ Specimen } & \multicolumn{2}{|l|}{ Vancomycin } & \multirow{2}{*}{$\begin{array}{l}\text { AMR } \\
\text { genes }\end{array}$} \\
\hline & & & & Susceptibility & $\mathrm{MIC}(\mu \mathrm{g} / \mathrm{mL})$ & \\
\hline ENC/UM/01 & E. faecium & $\mathrm{HA}$ & Blood & $\mathrm{R}$ & 32 & $\operatorname{van} \mathrm{A}, \operatorname{van} \mathrm{B}$ \\
\hline ENC/UM/32 & E. faecium & $\mathrm{HA}$ & Swab & $\mathrm{R}$ & $>256$ & $\operatorname{van} \mathrm{A}, \operatorname{van} \mathrm{B}$ \\
\hline ENC/UM/33 & E. faecalis & CA & Bone & $\mathrm{R}$ & 32 & $\operatorname{vanB}$ \\
\hline ENC/UM/46 & E. faecalis & $\mathrm{HA}$ & Tissue & 1 & 16 & $\operatorname{vanB}$ \\
\hline ENC/UM/52 & E. faecalis & CA & Bone & $\mathrm{R}$ & 32 & - \\
\hline ENC/UM/54 & E. faecalis & $H A$ & Blood & $\mathrm{R}$ & 32 & $\operatorname{vanB}$ \\
\hline ENC/UM/57 & E. faecalis & CA & Blood & $\mathrm{R}$ & $>256$ & $\operatorname{van} B$ \\
\hline
\end{tabular}


the A. baumannii were obtained from clinical specimens related to the respiratory sites $(69 \%)$. The A. baumannii were mostly MDR (89\%). All strains were resistant to imipenem, with MIC values ranging from $32 \mu \mathrm{g} /$ $\mathrm{mL}$ to $128 \mu \mathrm{g} / \mathrm{mL}\left(\mathrm{MIC}_{50}=128 \mu \mathrm{g} / \mathrm{mL}\right)$. Therefore, all strains were identified as carbapenem-resistant $A$. baumannii (CRAB). The majority of the CRAB strains were highly resistant to amikacin (87\%; MIC $\geq 256 \mu \mathrm{g} / \mathrm{mL}$ ), and all were highly resistant to piperacillin-tazobactam (MIC $\geq 512 / 4 \mu \mathrm{g} / \mathrm{mL}$ ). Colistin resistance was observed in $19 \%$ of the CRAB strains, with a low or moderate level of resistance $(8 \mu \mathrm{g} / \mathrm{mL} \leq \mathrm{MIC} \leq 32 \mu \mathrm{g} / \mathrm{mL})$.

The most encountered carbapenemase and extendedspectrum $\beta$-lactamase (ESBL) genes in our collection of CRAB strains were $b l a_{\text {OXA-23 }}(96 \%), b l a_{\mathrm{OXA}-51}(91 \%)$, and $b l a_{\mathrm{TEM}}(74 \%)$. Four strains harbored $b l a_{\mathrm{VEB}}$, all of which were isolated from ICU patients with HA-pneumonia. The carbapenemase and ESBL genes present in the CRAB strains are summarized in Table 3 . Other $\beta$-lactamase genes $\left(b l a_{\mathrm{IMP}}, b l a_{\mathrm{NDM}}, b l a_{\mathrm{VIM}}, b l a_{\mathrm{SHV}}, b l a_{\mathrm{CTX}-\mathrm{M}}, b l a_{\mathrm{PER}}\right.$, and $\left.b l a_{\mathrm{SIM}}\right)$ were absent from the A. baumannii strains collected in this study.

The most common AME gene that contributed to amikacin resistance in $\mathrm{CRAB}$ strains was the aadB gene (49\%). The $a a c \mathrm{~A} 4, a a c \mathrm{C} 1$, and $a a c \mathrm{C} 2$ genes were present in only $4 \%$ of the amikacin-resistant strains. The A. baumannii strains that harbored a combination of two AME genes (one strain with both $a a c \mathrm{C} 1$ and $\mathrm{C} 2$; one with $a a c \mathrm{~A} 4$ and $a a d \mathrm{~B}$; one with $a a c \mathrm{C} 1$ and $a a d \mathrm{~B}$ ) were found associated with HA-pneumonia in the ICUs.

\section{Pseudomonas aeruginosa}

The majority of the $P$. aeruginosa (63\%) examined in this study were associated with HA infections, six of which were isolated from patients admitted into ICU. More than half of the strains (56\%) were isolated from clinical specimens associated with the respiratory tract. The majority of the strains (80\%) showed a non-MDR phenotype. Although MDR phenotype was relatively uncommon among the $P$. aeruginosa compared to the MRSA

Table $3 \beta$-lactamase genes profile of the carbapenem-resistant A. baumannii strains

\begin{tabular}{|c|c|}
\hline Cabapenemase/ESBL genes profile & $\begin{array}{l}\text { Number } \\
\text { of } \\
\text { strains }\end{array}$ \\
\hline$b l a_{\mathrm{OXA}-23}, b l a_{\mathrm{OXA}-51}, b l a_{\mathrm{TEM}}$ & 33 \\
\hline$b / a_{\mathrm{OXA}-23}, b l a_{\mathrm{OXA}-51}$ & 12 \\
\hline$b l a_{\mathrm{OXA}-23}, b l a_{\mathrm{OXA}-51}, b a_{\mathrm{TEM}}, b l a_{\mathrm{VEB}}$ & 3 \\
\hline$b l a_{\mathrm{OXA}-23}, b l a_{\mathrm{TEM}}$ & 3 \\
\hline$b l a_{\mathrm{OXA}-23}, b l a_{\mathrm{OXA}-51}, b l a_{\mathrm{VEB}}$ & 1 \\
\hline$b / a_{\mathrm{TEM}}$ & 1 \\
\hline
\end{tabular}

and CRAB strains examined in this study, resistance to the first-line antibiotics in the aminoglycoside (amikacin), third generation cephalosporins (ceftazidime and cefotaxime), fluoroquinolone (ciprofloxacin), and carbapenem (imipenem and meropenem) families was at an alarming rate. Amikacin resistance was observed in $17 \%$ of the $P$. aeruginosa strains. One-fifth of the $P$. aeruginosa strains were ciprofloxacin-resistant (20\%), with MIC values ranging from $4 \mu \mathrm{g} / \mathrm{mL}$ to $256 \mu \mathrm{g} / \mathrm{mL}$ and above $\left(\mathrm{MIC}_{50}=64 \mu \mathrm{g} / \mathrm{mL}\right)$. All strains were resistant to cefotaxime, and $35 \%$ of the strains showed resistance or reduced susceptibility to ceftazidime. Thirty-nine percent of the strains were identified as carbapenemresistant $P$. aeruginosa (CRPA) strains, with $37 \%$ of the strains showing resistance or reduced susceptibility to both imipenem and meropenem. The MIC values of imipenem ranged from $4 \mu \mathrm{g} / \mathrm{mL}$ to $256 \mu \mathrm{g} / \mathrm{mL}$ and above $\left(\mathrm{MIC}_{50}=16 \mu \mathrm{g} / \mathrm{mL}\right)$ among the CRPA strains. The AmpC-type $\beta$-lactamase gene $\left(b l_{\mathrm{AmpC}}\right)$ was detected in $78 \%$ of the cephalosporin-resistant strains and $81 \%$ of the CRPA. When screened for the presence of metallo- $\beta$ lactamase (MBL) genes $\left(b l a_{\mathrm{IMP}}\right.$ and $\left.b l a_{\mathrm{VIM}}\right)$, only $b l a_{\mathrm{VIM}}$ was detected in $43 \%$ of the CRPA strains, while $b l a_{\mathrm{IMP}}$ was absent from all strains.

\section{Enterobacteriaceae-Enterobacter spp., Escherichia coli and Klebsiella pneumoniae}

A total of 162 Enterobacteriaceae strains, with 54 strains each from Enterobacter spp., E. coli, and K. pneumoniae, were collected and characterized in this study. The Enterobacter spp. strains collection is mainly comprised of the species cloacae $(\mathrm{n}=41)$ and strains from the E. cloacae complex $(\mathrm{n}=10)$, followed by aerogenes $(\mathrm{n}=1)$, asburiae $(\mathrm{n}=1)$, and hormaechaei $(\mathrm{n}=1)$. Majority of the Enterobacter spp. (61\%) and K. pneumoniae (72\%) were associated with HA infections. On the contrary, E. coli strains were slightly more common from community origins (54\%). All Enterobacteriaceae strains were screened for their activities against cephalosporins (ceftazidime, ceftriaxone, cefotaxime, cefepime, and cefoxitin), $\beta$-lactam combination agents (amoxicillin-clavulanate and piperacillin-tazobactam), aminoglycoside (amikacin), fluoroquinolone (ciprofloxacin), carbapenems (imipenem and meropenem), folate pathway antagonist (sulfamethoxazole-trimethoprim), and lipopeptide (colistin). High rates of MDR were observed in both E. coli and K. pneumoniae, but the Enterobacter spp. remained largely susceptible to the antimicrobial agents tested in this study. Amikacin was the only active antimicrobial agent against all Enterobacteriaceae strains.

The Enterobacter spp. remained largely susceptible to all antimicrobial agents tested, except for colistin (43\% resistance). Colistin resistance was relatively 
less common in E. coli (11\%) and K. pneumoniae (20\%). High rates of resistance to amoxicillin-clavulanate and cefoxitin among the Enterobacter spp. were expected due to intrinsic resistance. E. coli and $K$. pneumoniae both exhibited high rates of non-susceptibility to cephalosporins, amoxicillin-clavulanate, ciprofloxacin, and sulfamethoxazole-trimethoprim. K. pneumoniae strains showed greater resistance to piperacillin-tazobactam and carbapenems compared to the other two organisms. Figure 1 shows a comparison of the non-susceptibility rates of Enterobacteriaceae strains against selected antimicrobial agents.

All cefepime-resistant Enterobacteriaceae strains showed high-level resistance $\left(\mathrm{MIC}_{50}>256 \mu \mathrm{g} / \mathrm{mL}\right)$. Non-susceptible $E$. coli exhibited high-level fluoroquinolone and carbapenem resistance $\left(\mathrm{MIC}_{50} \geq 256 \mu \mathrm{g} /\right.$ $\mathrm{mL}$ ). Meanwhile, carbapenem-resistant $K$. pneumoniae (CRKP) was highly resistant to imipenem $\left(\mathrm{MIC}_{50}>256 \mu \mathrm{g} / \mathrm{mL}\right)$. All colistin-resistant strains showed a moderately high level of resistance $(8 \mu \mathrm{g} /$ $\mathrm{mL} \leq \mathrm{MIC}_{50} \leq 32 \mu \mathrm{g} / \mathrm{mL}$ ). The MIC data of the nonsusceptible Enterobacteriaceae strains are summarized in Table 4.

The most encountered ESBL genes in K. pneumoniae were $b l a_{\mathrm{SHV}}(94 \%), b l a_{\mathrm{CTXM}-1}(80 \%)$, and $b l a_{\mathrm{TEM}}(57 \%)$. The majority $(80 \%)$ of the ESBL-producing K. pneumoniae harbored at least two ESBL genes. The MBL gene $b l a_{\mathrm{NDM}}$ was detected in $20 \%$ of the K. pneumoniae, with one strain harboring two MBL genes $\left(b l a_{\mathrm{NDM}}\right.$ and $\left.b l a_{\mathrm{VIM}}\right)$. The carbapenemase gene $b l a_{\text {OXA-48 }}$ was detected only in $K$. pneumoniae $(\mathrm{n}=4)$. E. coli harbored mainly $b l a_{\mathrm{TEM}}(56 \%)$ and $b l a_{\text {CTXM-1 }}(37 \%)$ and was seen with a less diverse $\beta$-lactamase genes profile compared to $K$. pneumoniae. The MBL gene $b l a_{\mathrm{NDM}}$ was detected in a

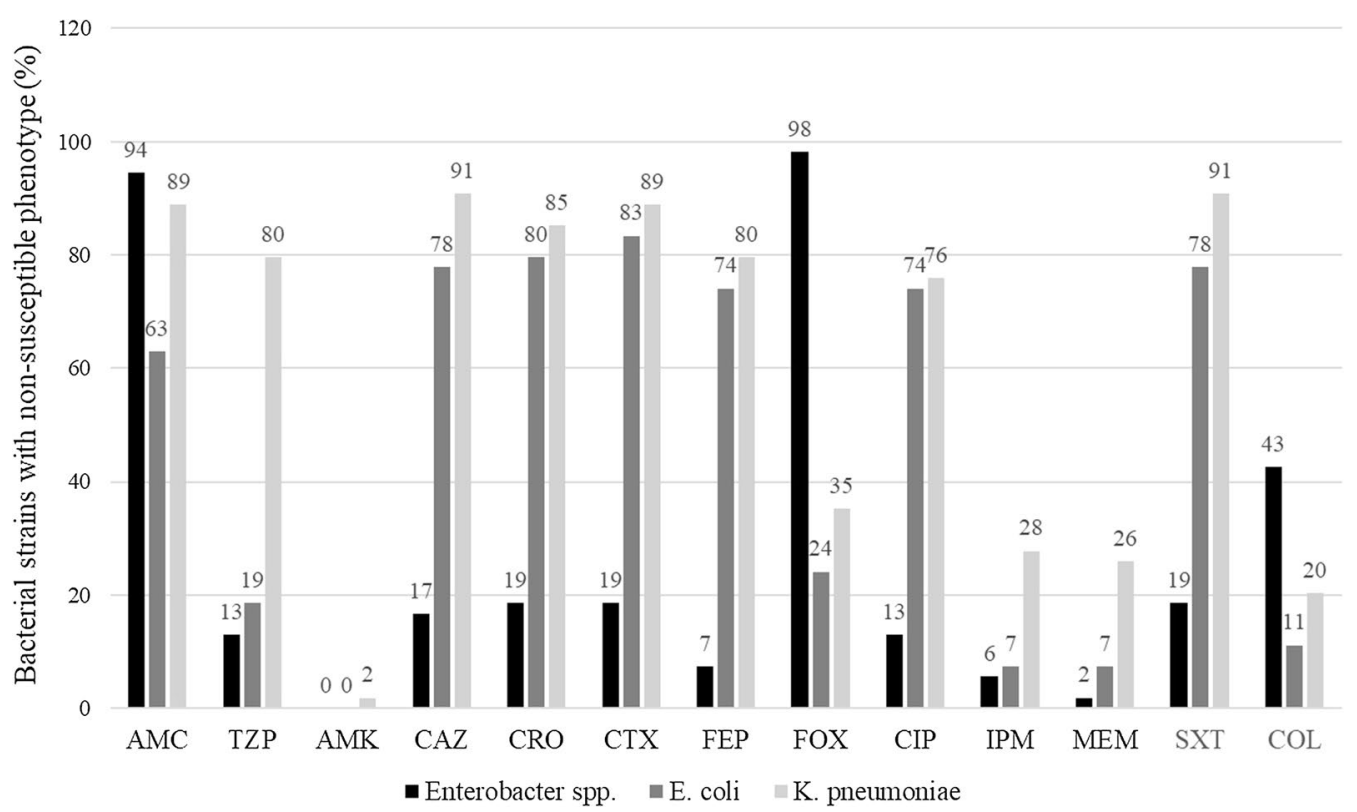

Fig. 1 Percentage of non-susceptible Enterobacteriaceae strains tested against selected antimicrobial agents. The number on top of each column indicates the percentage value. AMC: amoxicillin-clavulanate; TZP: piperacillin-tazobactam; AMK: amikacin; CAZ: ceftazidime; CRO: ceftriaxone; CTX: cefotaxime; FEP: cefepime; FOX: cefoxitin; CIP: ciprofloxacin; IPM: imipenem; MEM: meropenem; SXT: sulfamethoxazole-trimethoprim; COL: colistin

Table 4 Summary of $\mathrm{MIC}$ range and median $\left(\mathrm{MIC}_{50}\right)$ of selected antimicrobial agents for Enterobacteriaceae strains with nonsusceptible phenotypes

\begin{tabular}{|c|c|c|c|c|c|c|c|c|}
\hline \multirow[t]{2}{*}{ Organism } & \multicolumn{2}{|l|}{ Cefepime } & \multicolumn{2}{|c|}{ Ciprofloxacin } & \multicolumn{2}{|l|}{ Imipenem } & \multicolumn{2}{|l|}{ Colistin } \\
\hline & $\begin{array}{l}\text { MIC range } \\
(\mu \mathrm{g} / \mathrm{mL})\end{array}$ & $\begin{array}{l}\mathrm{MIC}_{50}(\mu \mathrm{g} / \\
\mathrm{mL})\end{array}$ & $\begin{array}{l}\text { MIC range } \\
(\mu \mathrm{g} / \mathrm{mL})\end{array}$ & $\begin{array}{l}\mathrm{MIC}_{50}(\mu \mathrm{g} / \\
\mathrm{mL})\end{array}$ & $\begin{array}{l}\text { MIC range } \\
(\mu \mathrm{g} / \mathrm{mL})\end{array}$ & $\begin{array}{l}\mathrm{MIC}_{50}(\mu \mathrm{g} / \\
\mathrm{mL})\end{array}$ & $\begin{array}{l}\text { MIC range } \\
(\mu \mathrm{g} / \mathrm{mL})\end{array}$ & $\begin{array}{l}\mathrm{MIC}_{50}(\mu \mathrm{g} / \\
\mathrm{mL})\end{array}$ \\
\hline $\begin{array}{l}\text { Enterobacter } \\
\text { spp. }\end{array}$ & $\geq 256$ & $>256$ & $2-256$ & 8 & $4-128$ & 4 & $8-64$ & 32 \\
\hline E. coli & $8-256$ & $>256$ & $0.5-256$ & $>256$ & $2-256$ & 256 & $4-64$ & 8 \\
\hline K. pneumoniae & $64-256$ & $>256$ & $0.5-256$ & 32 & $4-256$ & $>256$ & $4-64$ & 32 \\
\hline
\end{tabular}


Table 5 Summary of ESBL and carbapenemase gene profiles in K. pneumoniae and E. coli

\begin{tabular}{|c|c|c|}
\hline \multirow[t]{2}{*}{$\beta$-lactamase gene profile } & \multicolumn{2}{|c|}{ No. (\%) of strains } \\
\hline & K.pneumoniae & E. coli \\
\hline bla $a_{\mathrm{SH},}$, bla $a_{\mathrm{TEM}}$, bla $a_{\mathrm{CTXM}-1}$, bla $a_{\mathrm{NDM}}$, bla $a_{\mathrm{OXA}-48}$ & $1(2)$ & $0(0)$ \\
\hline$b l a_{\mathrm{SH},}, b l a_{\mathrm{TEM}}, b l a_{\mathrm{CTXM}-1}, b l a_{\mathrm{NDM}}$ & $9(17)$ & $0(0)$ \\
\hline$b l a_{\mathrm{SHV}}, b l a_{\mathrm{TEM}}, b l a_{\mathrm{CTXM}-1}, b l a_{\mathrm{OXA}-48}$ & $2(4)$ & $0(0)$ \\
\hline$b l a_{\mathrm{TEM}}, b l a_{\mathrm{CTXM}-1}, b l a_{\mathrm{NDM}}, b l a_{\mathrm{VIM}}$ & $1(2)$ & $0(0)$ \\
\hline$b l a_{\mathrm{TEM}}, b / a_{\mathrm{CTXM}-1}, b l a_{\mathrm{OXA}-48}$ & $1(2)$ & $0(0)$ \\
\hline bla $a_{\mathrm{SHV}}, b / a_{\mathrm{TEM}}, b l a_{\mathrm{CTXM}-1}$ & $16(30)$ & $0(0)$ \\
\hline$b l a_{\mathrm{SHV}} b l a_{\mathrm{CTXM}-1}$ & $12(22)$ & $1(2)$ \\
\hline$b / a_{\mathrm{SHV}}, b / a_{\mathrm{TEM}}$ & $0(0)$ & $2(4)$ \\
\hline$b / a_{\mathrm{TEM}}, b / a_{\mathrm{CTXM}-1}$ & $1(2)$ & $12(22)$ \\
\hline$b / a_{\text {CTXM-1 }}$ & $0(0)$ & $7(13)$ \\
\hline$b l a_{\mathrm{NDM}}$ & $0(0)$ & $1(2)$ \\
\hline$b / a_{\mathrm{SHV}}$ & $11(20)$ & $0(0)$ \\
\hline$b / a_{\mathrm{TEM}}$ & $0(0)$ & $16(30)$ \\
\hline
\end{tabular}

Table 6 Amino acid substitution profiles for ciprofloxacinresistant E. coli $(\mathrm{n}=40)$

\begin{tabular}{lll}
\hline Target gene & Amino acid substitution profile* & $\begin{array}{l}\text { No. (\%) of } \\
\text { strains }\end{array}$ \\
\hline gyrA & Ser-83-Leu; Asp-87-Asn; Leu-102-Ala & $4(10)$ \\
& Ser-83-Leu; Asp-87-Tyr; Gly-105-Val & $2(5)$ \\
& Ser-83-Leu; Asp-87-Asn & $14(35)$ \\
& Ser-83-Leu & $6(15)$ \\
gyrB & None & $37(93)$ \\
parC & Ser-80-Ile; Glu-84-Ile & $7(18)$ \\
& Ser-80-Ile & $16(40)$ \\
parE & Ser-458-Ala & $2(5)$ \\
\hline
\end{tabular}

*Ala: alanine; Asp: aspartate; Asn: asparagine; Glu: glutamate; Gly: glycine; lle: Isoleucine; Leu: leucine; Ser: serine; Tyr: tyrosine; Val: valine

carbapenem-resistant E. coli strain. Table 5 summarizes the $\beta$-lactamase gene profiles of the K. pneumoniae and E. coli strains examined in this study.

All Enterobacteriaceae strains with non-susceptible phenotype to ciprofloxacin were screened for the presence of plasmid-borne fluoroquinolone resistance-conferring genes ( $q n r \mathrm{~A}, q n r \mathrm{~B}$, and $q n r \mathrm{~S})$. Both $q \eta r \mathrm{~B}$ and $q n r \mathrm{~S}$ were detected in ciprofloxacin-resistant $E$. coli (10\% and 15\%), K. pneumoniae (61\% and 34\%), and Enterobacter spp. (14\% and $43 \%)$. A subset of the ciprofloxacinresistant K. pneumoniae (15\%) harbored both qnrB and $q n r S$. However, there was no indication that the presence of more than one qnr gene in the K. pneumoniae strain resulted in an increased MIC of ciprofloxacin. Sequence analysis of the quinolone resistance determining region (QRDR) in the DNA topoisomerase II (gyrAB) and IV
(parCE) genes was conducted to identify mutations in the ciprofloxacin-resistant E. coli strains. Amino acid substitutions that occurred in the QRDR of each gene are summarized in Table 6 . Half of the ciprofloxacin-resistant strains possessed more than one amino acid substitutions in gyrA QRDR. The detailed QRDR and $q n r$ genes profiles of the E. coli strains are shown in Additional file 1: Table S10.

\section{Correlation between AMR trends of the ESKAPEE strains and hospital-acquired infection}

Risk factors associated with HA infections caused by each of the ESKAPEE organisms were identified. Logistic regression using forward stepwise selection was undertaken to control the effect of confounding variables. All variables with a significant association with $\mathrm{HA}$ infections $(\mathrm{p}<0.1)$ were entered into the logistic regression model. The outcome of the analysis is expressed as odds ratios, $\operatorname{Exp}(\mathrm{B})$, indicating the chances of HA infection occurring in the patient. A summary of the correlation analysis results is shown in Table 7.

\section{Discussion}

We report herein the genotypes and phenotypes of the AMR-ESKAPEE pathogens isolated from a tertiary hospital located in the capital Kuala Lumpur, Malaysia. A total of 378 bacterial strains, with each species represented by 54 strains, were collected over a nine-month study period via the convenient sampling method. All ESKAPEE pathogens were mainly associated with HA infections, except for $E$. coli, whereby slightly more than half of the strains were obtained from community origins. MDR phenomenon was commonly observed among the strains, and the presence of multiple AMR-conferring genes was detected. Most of these AMR strains were isolated from respiratory sites, blood, body fluids, and urine samples.

We observed an increased prevalence of VRE when compared to recent studies within the same geographical region. Moussa and colleagues reported a $4 \%$ occurrence of VRE among the 75 enterococci strains obtained in Hospital Kuala Lumpur (HKL), all of which were $E$. faecalis [17]. An earlier study by Daniel et al. examining 22 E. faecalis strains from Hospital Serdang did not identify any VRE strains [18]. All three hospitals, including UMMC in this study, are located in Klang Valley within close proximity of each other. Previous studies reported a greater prevalence of the vanA gene among Malaysian VRE strains isolated from various sources, including humans, farmed animals, and even within the natural environment $[18,19]$. However, we observed that the van $\mathrm{B}$ gene occurred more frequently in the VRE strains identified in this study. Both $\operatorname{van} \mathrm{A}$ and $\operatorname{van} \mathrm{B}$ genes are 
Table 7 Factors associated with hospital-acquired infections

\begin{tabular}{|c|c|c|c|c|c|}
\hline \multirow[t]{2}{*}{ Organism } & \multirow[t]{2}{*}{ Risk factor* } & \multirow[t]{2}{*}{ P-value } & \multirow[t]{2}{*}{ OR } & \multicolumn{2}{|l|}{$95 \% \mathrm{Cl}$} \\
\hline & & & & Lower & Upper \\
\hline \multirow[t]{3}{*}{ Enterococcus spp. } & Gender & 0.0757 & - & - & - \\
\hline & Ampicillin resistance & 0.0757 & 3.13 & 0.86 & 11.37 \\
\hline & Streptomycin resistance & 0.01431 & - & - & - \\
\hline \multirow[t]{5}{*}{ S. aureus } & MDR & 0.014 & - & - & - \\
\hline & Clindamycin/Erythromycin resistance & 0.014 & - & - & - \\
\hline & Cefoxitin/Oxacillin resistance & $<0.001$ & 7.62 & 1.36 & 42.71 \\
\hline & Linezolid/Rifampicin/Vancomycin resistance & $<0.001$ & - & - & - \\
\hline & AMR genes & 0.02 & - & - & - \\
\hline \multirow[t]{5}{*}{ K. pneumoniae } & Gender & 0.06136 & - & - & - \\
\hline & Race & 0.1082 & - & - & - \\
\hline & Ciprofloxacin resistance & 0.1 & - & - & - \\
\hline & Imipenem resistance & 0.1285 & - & - & - \\
\hline & Colistin resistance & $<0.001$ & - & - & - \\
\hline \multirow[t]{2}{*}{ A. baumannii } & Imipenem/Piperacillin-tazobactam/Colistin resistance & $<0.001$ & - & - & - \\
\hline & AMR genes & 0.1185 & - & - & - \\
\hline \multirow[t]{5}{*}{$P$. aeruginosa } & Ceftazidime resistance & 0.01721 & 5.04 & 1.24 & 20.43 \\
\hline & Cefotaxime resistance & 0.05676 & - & - & - \\
\hline & Imipenem resistance & 0.1083 & - & - & - \\
\hline & Meropenem resistance & 0.0468 & - & - & - \\
\hline & AMR Genes & 0.113 & - & - & - \\
\hline \multirow[t]{3}{*}{ Enterobacter spp. } & Amikacin resistance & 0.1025 & - & - & - \\
\hline & Ceftazidime resistance & 0.0611 & - & - & - \\
\hline & Ceftriaxone/Cefotaxime resistance & 0.0379 & 7.50 & 0.87 & 64.36 \\
\hline \multirow[t]{3}{*}{ E. coli } & Gender & 0.1056 & - & - & - \\
\hline & MDR & 0.09166 & - & - & - \\
\hline & Piperacillin-tazobactam resistance & 0.09584 & - & - & - \\
\hline
\end{tabular}

*AMR: antimicrobial resistance; MDR: multidrug resistance; OR: odds ratios; Cl: confidence interval

responsible for acquired vancomycin resistance in enterococci, although vanA confers a higher level of inducible resistance compared to variable levels of inducible resistance conferred by $v a n B$ genes [20]. Indeed, the VRE strains in this study harboring vanB only showed variable vancomycin MIC values $(16 \mu \mathrm{g} / \mathrm{mL}$ to $>256 \mu \mathrm{g} / \mathrm{mL})$. The greater prevalence of $v a n \mathrm{~B}$-harboring VRE in our study site may indicate a possible shift in the predominant VRE genotype in this region. Nonetheless, a further study involving a larger sample size or more diverse sampling sites should be conducted to determine if the observed change in the predominance is a localized or nationwide event.

The enterococci strains in our sample pool showed a slightly lower prevalence of HLAR (39\%) compared to a similar study within the same region. A recent study in HKL documented 45-49\% HLAR, concerning streptomycin resistance, among the enterococci strains [17]. In the HKL study, the $a a c\left(6^{\prime}\right)-I e-a p h\left(2^{\prime \prime}\right)-I a$ AME gene was most common among the HLAR enterococci, accounting for their high level of resistance to gentamicin. The authors reported that the presence of another AME gene, aph(3')-IIIa, could have attributed to the high-level streptomycin resistance among their strains collection. However, our enterococci strains showed a greater prevalence of $\operatorname{ant}\left(4^{\prime}\right)-I a(22 \%)$, followed by aph( $\left.2^{\prime \prime}\right)-I c$ (15\%), and a total absence of aph(3')-IIIa. The HKL study did not screen for $a n t\left(4^{\prime}\right)-I a$, and none of the strains carried $\operatorname{aph}\left(2^{\prime \prime}\right)-I c$ gene [17]. Given that AME genes are responsible for acquired aminoglycoside resistance through horizontal gene transfer, we infer that there might be different lineages of aminoglycoside resistant enterococci currently circulating in this region, each lineage developing resistance through a separate evolutionary pathway.

The association of MDR-MRSA with HA infections and the isolation of mainly drug-susceptible MSSA strains from community origins, as observed in this study, is a common phenomenon among Malaysian S. aureus populations [21, 22]. Nonetheless, we observed an occurrence of $28 \%$ CA-MRSA, the majority of which were MDR 
(70\%). The increasing prevalence of CA-MRSA has been documented globally, mainly in the Western regions, and gradually replacing the dominant pandemic HA-MRSA clone ST239/ST241-III [23]. The genetically diverse CAMRSA is known to be a successful colonizer capable of causing a wide range of diseases from mild skin and soft tissue infections to severe systemic infections [23]. This notion is reflected in our CA-MRSA collection from various clinical specimens including pus, blister fluid, blood, sputum, and bronchoalveolar lavage.

We observed simultaneous resistance to cefoxitin and oxacillin among the MRSA strains identified in this study, all of which carrying the mecA gene. This finding corresponds with the prediction of mecA-mediated methicillin (oxacillin) resistance based on the cefoxitin-resistant phenotype of the strains [15]. Throughout the years, mecA-mediated resistance has been the sole mechanism of resistance among MRSA populations in Malaysia [22, 24]. Only until very recently that the presence of the $m e c \mathrm{C}$ gene is documented among livestockassociated MRSA strains isolated in Northern Malaysia, at an alarming rate of $16 \%$, some co-existing with the $m e c \mathrm{~A}$ gene [25]. This shows that the novel $m e c \mathrm{C}$ gene has spread beyond Europe and is currently emerging in Malaysia. We recommend screening for the $m e c C$ gene in future genotyping of clinical $S$. aureus strains to understand the molecular epidemiology and correlated clinical outcomes of this genotype.

Although all S. aureus strains examined in this study remained susceptible to vancomycin, the subset of strains (40\%) with a relatively higher MIC value $(1 \mu \mathrm{g} /$ $\mathrm{mL}$ ) within the susceptible range of vancomycin should not be neglected. Reduced susceptibility of $S$. aureus to vancomycin has been increasingly reported worldwide, constituting one of the major global AMR problems [26]. Heterogeneous vancomycin-intermediate S. aureus (hVISA) associated with treatment failure has emerged in Malaysian hospitals since 2009 and was increasingly reported during the past decade [27, 28]. Local health authorities should closely monitor vancomycin use in the healthcare settings to slow down, if not completely prevent, the development of resistance to this last-resort drug for the treatment of MRSA infections.

In the hospital diagnostic laboratory, S. aureus strains that were identified as erythromycin-resistant are assumed to conform to inducible macrolide-lincosamide-streptogramin $\mathrm{B}\left(\mathrm{iMLS}_{\mathrm{B}}\right)$ phenotype, i.e. inducible clindamycin resistance. This assumption is essential in the clinical setting, given that $\mathrm{iMLS}_{\mathrm{B}} \mathrm{S}$. aureus shows in vitro susceptibility to clindamycin, hence may lead to therapeutic failure. We observed clindamycin resistance and potential $\mathrm{iMLS}_{\mathrm{B}}$ in $80 \%$ of the MRSA strains, and none in MSSA strains. Similar studies in Malaysia have reported the greater prevalence of clindamycin resistance and $\mathrm{iMLS}_{\mathrm{B}}$ in MRSA from both clinical (47\%) and community (75\%) settings [22, 29]. A study conducted in East Coast Malaysia has identified that the $\mathrm{iMLS}_{\mathrm{B}} \mathrm{S}$. aureus predominantly harbored $m s r$ A gene which confers erythromycin resistance, with the $\mathrm{erm} \mathrm{C}$ gene detected in only a single $\mathrm{iMLS}_{\mathrm{B}}$ strain [22]. On the contrary, all erythromycin-resistant MRSA strains in our collection harbored the erm $\mathrm{C}$ gene. This genotype is common in macrolideresistant MRSA clones in Europe [30]. Therefore, we infer that the $\mathrm{iMLS}_{\mathrm{B}}$ MRSA from the East and West Coast Malaysia constituted two different clonal lineages. Nonetheless, a further study involving a larger sample size is essential to verify this notion.

MDR A. baumannii has been extensively associated with HA infections, often pneumonia, in hospitalized patients especially in the ICUs in Malaysian hospitals [31]. We identified two CA-MDR-CRAB strains isolated from swab and urine specimens of patients admitted to UMMC. Although the CA-MDR-CRAB strains in this study were not associated with life-threatening infections, the presence of MDR A. baumannii in the community should not be neglected, as they are capable of causing severe pneumonia in otherwise healthy individuals [32]. The AMR trends and resistance mechanisms of A. baumannii in clinical settings have been extensively studied in Peninsular Malaysia over the past thirty years [31]. Nationwide surveillance by the Ministry of Health $(\mathrm{MOH})$ Malaysia has documented a $50-60 \%$ resistance rates to carbapenems [33]. However, the frequency of CRAB in hospitals located in Kuala Lumpur, including UMMC, often exceeds the national rates (70-98\%) [34, 35]. Similar to other reported studies in this region, the predominant carbapenemase genes identified among the CRAB strains in our collection are $b l a_{\mathrm{OXA}-23}$ and bla OXA-51 $[31,34]$. Additional factors compounding the challenges with AMR include the ubiquitous presence of the ESBL gene $b l a_{\mathrm{TEM}}$ in conjunction with the carbapenemase genes which might have contributed to the relatively high levels of resistance to the antimicrobial agents tested $\left(\mathrm{MIC}_{50} \geq 128 \mu \mathrm{g} / \mathrm{mL}\right)$. We detected four CRAB strains harboring the acquired ESBL gene $b l a_{\mathrm{VEB}}$. The bla $a_{\mathrm{VEB}}$-carrying $A$. baumannii has been mainly reported in Europe and the Middle East causing nationwide outbreaks and HA infections [36-38]. In the Southeast Asian region, a study on class I integron revealed that the bla $a_{\mathrm{VEB}}$-carrying $A$. baumannii in Thailand is genetically linked to the European clones [39]. Therefore, the emergence of $b l a_{\mathrm{VEB}}$-carrying CRAB strains in Malaysia could be a result of foreign clonal invasion or the exchange of genetic elements between local and global strains.

Approximately one-fifth of the CRAB strains were resistant to colistin, one of the last-resort drugs for the 
treatment of MDR A. baumannii infections. A high rate of resistance to polymyxin (26\%) was also documented in a hospital located on the East Coast of Malaysia [40]. Combination therapy using colistin/rifampicin or colistin/carbapenem is recommended for treating MDR $A$. baumannii infections [41]. However, the high rates of carbapenem resistance among Malaysian MDR A. baumannii have left us with limited therapeutic options. Studies on the prevalent aminoglycoside resistance mechanisms among Malaysian A. baumannii has not been previously reported. We found that the amikacinresistant $\mathrm{CRAB}$ in this study predominantly harbored the $\operatorname{aad} \mathrm{B}$ gene. Interestingly, the $a p h \mathrm{~A} 6$ gene that confers amikacin resistance was not detected among the strains [42]. Therefore, amikacin resistance among the CRAB strains could be attributable to other AME genes such as $\operatorname{ant}\left(2^{\prime}\right)-I a, \operatorname{aph}\left(3^{\prime}\right)-\mathrm{VIa}, \operatorname{aac}\left(3^{\prime}\right)-I a$, or the upregulation of the efflux pump gene adeB [43]. Nonetheless, this notion requires further verification via a thorough genetic study on the aminoglycoside resistance mechanisms.

Similar to A. baumannii, $P$. aeruginosa is often associated with HA pneumonia. P. aeruginosa is one of the leading nosocomial pathogens in UMMC since the early 2000s [44]. The nationwide AMR surveillance revealed overall ceftazidime, ciprofloxacin, and carbapenems resistance rates of less than $10 \%$ among the $P$. aeruginosa populations in Malaysia [33]. When compared to the national surveillance data, the AMR P. aeruginosa strains in our study showed higher rates of resistance to the named antimicrobial agents (20-37\%). Interestingly, we observed a marked reduction in the AMR rates of $P$. aeruginosa when compared to a study conducted in UMMC approximately 10 years ago, which recorded extremely high rates of resistance to similar antimicrobial agents (74-92\%) [45]. Similar high rates of resistance in $P$. aeruginosa were also documented in another two hospitals located within the same geographical location, at around the same period [46, 47]. An even earlier UMMC study in 2005 showed only $10-11 \%$ of $P$. aeruginosa were resistant to the same agents [48]. The fluctuation in the AMR rates of $P$. aeruginosa within the past two decades could have been a result of competition between antimicrobial stewardship and the microevolution of the pathogen. Effective antimicrobial stewardship programs (ASPs) might successfully reduce the rates of resistance, but the organism can develop different resistance mechanisms through horizontal gene transfers or mutations, or a different resistant clone might gain dominance in the same setting.

The persistence of CRPA has been a long-term nosocomial problem in UMMC. Multiple studies have been conducted intermittently by different research groups to understand the molecular epidemiology of CRPA in this institution. CRPA carrying an acquired MBL gene $b l a_{\text {IMP-7 }}$ has emerged in 1999, isolated from the peritoneal fluid of an 8-year-old child [49]. A retrospective study that screened CRPA strains isolated between 2005-2008 has detected four MBL gene variants, namely $b l a_{\text {IMP-7 }}$ (13\%), bla $\mathrm{IMP}-4_{\mathrm{I}}(2 \%), b l a_{\mathrm{VIM}-2}(19 \%)$, and $b l a_{\mathrm{VIM}-11}(1 \%)$ [50]. DNA fingerprinting results revealed that the $b l a_{\mathrm{IMP}^{-}}$ and $b l a_{\mathrm{VIM}}$-carrying CRPA constituted two distinctive clones [51]. The detection of only bla $\mathrm{VIM}^{- \text {carrying CRPA }}$ in the current study suggested the evolutionary success of this clone, indicated by its decade-long persistence in this institution. A recent study conducted in a hospital located in Johor (Southern Malaysia) has discovered MBL gene variants that were not previously reported in Malaysian CRPA, namely $b l a_{\mathrm{IMP}-1}$ and $b l a_{\mathrm{NDM}-1}$ [52]. Besides MBL genes, the ubiquitous AmpC-type $\beta$-lactamase gene present in the cephalosporin-resistant and CRPA (in this study) could have contributed to the resistance phenotypes [53].

MDR Enterobacteriaceae is one of the greatest public health threats worldwide, with an ever-increasing trend of ESBL-producing strains at 5.4\% per annum [54]. Multiple studies have investigated the AMR mechanisms of ESBL-producing E. coli and $K$. pneumoniae in Malaysia. The most encountered ESBL genes among these two organisms are $b l a_{\mathrm{TEM}}, b l a_{\mathrm{SHV}}$, and $b l a_{\mathrm{CTXM}}[55,56]$. Similar observations were made in our study. Besides, the $K$. pneumoniae strains examined in this study harbored a more diverse range of ESBL genes compared to E. coli. Clinical strains of the Enterobacteriaceae family in Malaysia has long been known to exchange AMR determinants via horizontal gene transfer, for instance, the transfer of R-plasmids [57]. Co-occurrence of K. pneumoniae strains harboring multiple ESBL genes with other Enterobacteriaceae organisms in the hospital environment greatly enhances the development of cephalosporin resistance among the nosocomial pathogens [58].

Carbapenem-resistant Enterobacteriaceae (CRE) is a growing public health threat in most parts of the world [59]. We observed a higher frequency of carbapenem resistance among $K$. pneumoniae compared to $E$. coli and Enterobacter spp. Both carbapenem-resistant $K$. pneumoniae (CRKP) and E. coli (CREC) showed highlevel resistance to imipenem $\left(\mathrm{MIC}_{50} \geq 256 \mu \mathrm{g} / \mathrm{mL}\right)$. The majority of the CRE (82\%) were simultaneously resistant to both imipenem and meropenem. These genes were more common among the CRKP ( $b l a_{\mathrm{NDM}}$ and $\left.b l a_{\mathrm{VIM}}\right)$, with only one CREC carried a bla $a_{\mathrm{NDM}}$ gene. The higher rate of carbapenem resistance in $K$. pneumoniae with a predominantly $b l a_{\mathrm{NDM}}$ genotype is a common phenomenon in Malaysian hospitals [60, 61]. The bla $\mathrm{NDM}^{- \text {carrying }}$ CRKP currently circulating in Malaysia could have been imported from India [62]. We detected the presence of $b l a_{\mathrm{VIM}}$ in CRKP, which had not been previously identified 
among $K$. pneumoniae in Malaysia. Besides MBL genes, the OXA carbapenemase gene that is most prevalent among CRE, bla $a_{\text {OXA-48, }}$, was also found in our CRKP [59]. Strains harboring these two carbapenemases (NDM and OXA) appeared common among the CRE populations in Southeast Asia [63]. Based on our analysis, CRKP carrying only $b l a_{\text {OXA-48 }}$ had a lower MIC of imipenem $\left(\mathrm{MIC}_{\mathrm{IPM}}=4 \mu \mathrm{g} / \mathrm{mL}\right)$ compared to strains carrying the MBL gene(s) $\left(\mathrm{MIC}_{\mathrm{IPM}}>256 \mu \mathrm{g} / \mathrm{mL}\right)$. The ability of the MBL genes to confer high-level carbapenem resistance could explain the shift from a predominantly $b l a_{\mathrm{OXA}-48^{-}}$

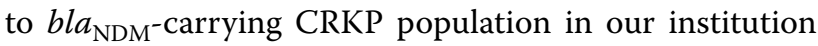
from 2013 to the current [64].

Increasing resistance to colistin, the last-resort drug for treating CRE infections, is currently on the rise on a global scale but under-reported in Southeast Asian countries [63]. To date, the MOH Malaysia has only been monitoring colistin resistance among $P$. aeruginosa in local hospitals, recording a slightly increased rate of resistance in 2018 within five years from 2013 (from 0.43\% to 0.6\%) [33]. We recorded the highest rate of colistin resistance in Enterobacter spp. (43\%), followed by $K$. pneumoniae $(20 \%)$ and E. coli (11\%). This observation is in agreement with the global surveillance that identified Enterobacter as the most common Enterobacteriaceae species that developed colistin resistance in clinical settings [65]. Among the colistin-resistant strains in this study, four were CRKP $\left(4 \mu \mathrm{g} / \mathrm{mL} \leq \mathrm{MIC}_{\mathrm{COL}} \leq 32 \mu \mathrm{g} / \mathrm{mL}\right)$ and two were CR-Enterobacter $\left(\mathrm{MIC}_{\mathrm{COL}}>64 \mu \mathrm{g} / \mathrm{mL}\right)$. Reports on colistin-resistant Enterobacteriaceae are rarely documented in Malaysia. There were only a few studies that reported colistin resistance among $K$. pneumoniae, with a higher incidence in zoonotic strains from swine farms compared to clinical strains $[55,66,67]$. We observed emerging colistin resistance among the CRE in the clinical setting. Therefore, increasing efforts to strengthen surveillance of this phenotype in local hospitals is essential to better understand the extent and impact of this public health problem.

Another major AMR problem associated with Enterobacteriaceae is fluoroquinolone resistance. Two important genetic mechanisms that confer fluoroquinolone resistance to Enterobacteriaceae are chromosomal mutation in the QRDR of the DNA topoisomerases and plasmid-borne $q n r$ genes [68]. We detected $q n r \mathrm{~B}$ and $q n r \mathrm{~S}$ in the ciprofloxacin non-susceptible strains, with the highest frequency in K. pneumoniae, some of which harbored both $q u r$ genes. Constant absence of $q n r \mathrm{~A}$ has been observed among Enterobacteriaceae in Malaysia [69, 70]. The regular use of quinolone antibiotics in our country might not favor the selection of strains with qnrA as it only confers low-level resistance to quinolone [71]. Mutations in the QRDR of gyrA and parC are common among Enterobacteriaceae isolated worldwide [72]. We identified amino acid substitution hotspots at Ser-83 and Asp-87 in gyrA, and Ser-80 and Glu-84 in parC, generally conferring a higher level of ciprofloxacin resistance compared to wild type strains. Mutations at these sites and/or the presence of $q n r \mathrm{~B}$ or $q n r \mathrm{~S}$ seemed to be the common phenotypes of fluoroquinolone-resistant Enterobacteriaceae in this region $[69,70,73]$. We detected two novel mutations in the gyrA QRDR of E. coli, namely Leu-102Ala and Gly-105-Val, not reported in previous literature [74]. Similar to previous reports, mutations were rare in gyrB and parE among our E. coli strains $[69,70]$.

We identified four factors that were linked with an increased risk of HA infection: ampicillin-resistant Enterococcus spp. (3.13 times higher chance), MRSA (7.62 times), ceftazidime-resistant $P$. aeruginosa (5.04 times), and ceftriaxone/cefotaxime-resistant Enterobacter spp. (7.5 times). In general, resistance to $\beta$-lactam antibiotics among the ESKAPEE organisms, except for S. aureus, is a significant predictor for patients' chances of acquiring infections in hospital settings. A review of the current antimicrobial stewardship program in the hospital should be conducted to assess the use of these antimicrobial agents in the institution. Enhancement of current infection control practices should be made concurrently to reduce the rate of $\mathrm{HA}$ infections caused by these AMR organisms.

\section{Conclusions}

In summary, data obtained in this study may provide valuable insight into the AMR trends and the major genetic mechanisms that conferred resistance to the ESKAPEE pathogens isolated from a tertiary hospital located in the capital city Kuala Lumpur, in the central region of Peninsular Malaysia. Our study included only a limited number of bacterial strains representing each of the ESKAPEE species, hence may not completely reflect the actual AMR prevalence of these organisms in this region. Nonetheless, this is the first report in Malaysia that collectively assessed the phenotypic and genotypic characteristics of the seven bacterial species that are of great public health importance in healthcare settings. Our findings may serve as the cornerstone for future works on the molecular epidemiology of ESKAPEE pathogens in this region. Furthermore, given that AMR is no longer a rare phenomenon in local settings, our selective evaluation of AMR-ESKAPEE strains provided greater insight into the MDR phenomenon and the genetic drives that gave rise to the common AMR phenotypes of these organisms. This information may contribute to making better-informed decisions on appropriate antibiotic prescription plans and infection control strategies in local hospitals. 


\begin{abstract}
Abbreviations
AME: Aminoglycoside-modifying enzyme; AMR: Antimicrobial resistance; ASP: Antimicrobial stewardship program; CA: Community-acquired; Cl: Confidence intervals; CLSI: Clinical and Laboratory Standards Institute; CRAB: Carbapenemresistant A. baumannii; CRE: Carbapenem-resistant Enterobacteriaceae; CRKP: Carbapenem-resistant K. pneumoniae; CRPA: Carbapenem-resistant P. aeruginosa; DNA: Deoxyribonucleic acid; ESBL: Extended-spectrum $\beta$-lactamase; ESKAPEE: Enterococcus Spp., Staphylococcus aureus, Klebsiella pneumoniae, Acinetobacter baumannii, Pseudomonas aeruginosa, Enterobacter spp., and Escherichia coli; HA: Hospital-acquired; HAl: Hospital-acquired infections; HCAl: Healthcare-associated infection; HGT: Horizontal gene transfer; HKL: Hospital Kuala Lumpur; hVISA: Heterogeneous vancomycin-intermediate S. aureus; ICU: Intensive care unit; iMLS: Inducible macrolide-lincosamide-streptogramin B; MBL: Metallo- $\beta$-lactamase; MDRO: Multidrug-resistant organism; MIC: Minimum inhibitory concentration; MRSA: Methicillin-resistant S. aureus; MSSA: Methicillin-susceptible S. aureus; OR: Odds ratios; PCR: Polymerase chain reaction; QRDR: Quinolone resistance determining region; UMMC: University of Malaya Medical Centre; VRE: Vancomycin-resistant enterococci; WHO: World Health Organization.
\end{abstract}

\section{Supplementary Information}

The online version contains supplementary material available at https://doi. org/10.1186/s13756-021-00936-5.

Additional file 1. PCR primers and conditions used for the identification of ESKAPEE strains (Table S1) and the characterization of AMR genes profile of each bacterial species (Table S2), detailed AMR features of the ESKAPEE strains (Table S3-S9), and QRDR mutations and qnr genotypes of ciprofloxacin non-susceptible E. coli strains (Table S10).

\section{Acknowledgements}

Disclaimer: MJG and TH are military service members. This work was prepared as part of their official duties. Title 17, U.S.C., §105 provides that copyright protection under this title is not available for any work of the U.S. Government. Title 17, U.S.C., \$101 defines a U.S. Government work as a work prepared by a military service member or employee of the U.S. Government as part of that person's official duties. The views expressed in this article are those of the authors and do not necessarily reflect the official policy or position of the U.S. Department of the Navy, the U.S. Department of Defense or the US government. We would like to thank Vysnova Partners, Inc. for the management of the research project.

\section{Authors' contributions}

Conceptualization, TH and CSJT; Resources, CSJT, TH, and MJG; Methodology, TH and CSJT; Investigation, STN, SNT, NI, KAJ, and SSLSP; Formal analysis, STN, CWC, SNT, NI, KAJ, and SSLSP; Visualization, STN and CWC; Writing-Original Draft, TH, CSJT and STN; Supervision, CSJT and MJG. All authors have read and agreed to the published version of the manuscript.

\section{Funding}

This study is funded by the United States of America Naval Medical Research Unit No. TWO (NAMRU-2) (Grant number: IF004-2020) and the Armed Forces Health Surveillance Division, Global Emerging Infections Surveillance \#P0107_19_NA, WUN D0016.

\section{Availability of data and materials}

All data generated or analyzed during this study are included in this published article [and its supplementary information files].

\section{Declarations}

\section{Ethics approval and consent to participate}

This study was approved by the Medical Research Ethics Committee of the University of Malaya Medical Center on $5^{\text {th }}$ September 2019 (MRECID.NO: 2019815-7748) and extramural research review in accordance with the U.S.
Navy Human Research Protection Program (HPRO.NAMRU2.2019.0009). All research activities conformed to the principles embodied in the Declaration of Helsinki.

\section{Consent for publication}

Not applicable.

\section{Competing interests}

The authors declare that they have no competing interests.

\section{Author details}

${ }^{1}$ Department of Medical Microbiology, Faculty of Medicine, Universiti Malaya, 50603 Kuala Lumpur, Malaysia. ${ }^{2}$ School of Pharmacy, Monash University Malaysia, 47500 Bandar Sunway, Selangor, Malaysia. ${ }^{3}$ Department of Medicine, Faculty of Medicine, Universiti Malaya, 50603 Kuala Lumpur, Malaysia. ${ }^{4}$ United States Naval Medical Research Unit Two (NAMRU-2), Phnom Penh, Cambodia.

Received: 6 December 2020 Accepted: 9 April 2021

Published online: 23 April 2021

\section{References}

1. World Health Organization (WHO). Antimicrobial resistance: Global report on surveillance. Geneva: World Health Organization (WHO); 2014.

2. Aslam B, Wang W, Arshad MI, Khurshid M, Muzammil S, Rasool MH, et al. Antibiotic resistance: a rundown of a global crisis. Infect Drug Resist. 2018;11:1645-58.

3. Tacconelli E, Carrara E, Savoldi A, Harbarth S, Mendelson M, Monnet DL, et al. Discovery, research, and development of new antibiotics: the WHO priority list of antibiotic-resistant bacteria and tuberculosis. Lancet Infect Dis. 2018;18:318-27.

4. Witte W. Antibiotic resistance. Int J Med Microbiol. 2013;303:285-6.

5. Cantas L, Shah SQ, Cavaco LM, Manaia C, Walsh F, Popowska M, et al. A brief multi-disciplinary review on antimicrobial resistance in medicine and its linkage to the global environmental microbiota. Front Microbiol. 2013;4:96.

6. Holmes AH, Moore LSP, Sundsfjord A, Steinbakk M, Regmi S, Karkey A, et al. Understanding the mechanisms and drivers of antimicrobial resistance. Lancet. 2016;387:176-87.

7. Dupont H, Friggeri A, Touzeau J, Airapetian N, Tinturier F, Lobjoie E, et al. Enterococci increase the morbidity and mortality associated with severe intra-abdominal infections in elderly patients hospitalized in the intensive care unit. J Antimicrob Chemoth. 2011;66:2379-85.

8. Michalopoulos A, Fotakis D, Virtzili S, Vletsas C, Raftopoulou S, Mastora Z, et al. Aerosolized colistin as adjunctive treatment of ventilator-associated pneumonia due to multidrug-resistant Gram-negative bacteria: a prospective study. Resp Med. 2008;102:407-12.

9. Jean SS, Hsueh PR. High burden of antimicrobial resistance in Asia. Int J Antimicrob Ag. 2011;37:291-5.

10. World Health Organization (WHO). Report on the burden of endemic health care-associated infection worldwide. Geneva: World Health Organization (WHO); 2011.

11. Vasudevan A, Mukhopadhyay A, Yuen EGY, Li J, Tambyah PA. Risk factors for infection/colonization caused by resistant Gram-negative bacilli in critically ill patients (An observational study of 1633 critically ill patients). Prev Med. 2012;57:S70-3.

12. Mauldin PD, Salgado CD, Hansen IS, Durup DT, Bosso JA. Attributable hospital cost and length of stay associated with health care-associated infections caused by antibiotic-resistant Gram-negative bacteria. Antimicrob Agents Ch. 2010;54:109-15.

13. Zingg W, Holmes A, Dettenkofer M, Goetting T, Secci F, Clack L, et al. Hospital organisation, management, and structure for prevention of healthcare-associated infection: A systematic review and expert consensus. Lancet Infect Dis. 2015;15:212-24.

14. Santajit S, Indrawattana N. Mechanisms of antimicrobial resistance in ESKAPE pathogens. BioMed Res Int. 2016;2016:2475067.

15. Clinical and Laboratory Standards Institute (CLSI). Performance Standards for Antimicrobial Susceptibility Testing, 30th Ed. CLSI supplement M100. Wayne, Pennsylvania, United States of America: Clinical and Laboratory Standards Institute; 2020. 
16. Kumar S, Stecher G, Li M, Knyaz C, Tamura K. MEGA X: Molecular evolutionary genetics analysis across computing platforms. Mol Biol Evol. 2018;35(6):1547-9.

17. Moussa AA, Md Nordin AF, Hamat RA, Jasni AS. High level aminoglycoside resistance and distribution of the resistance genes in Enterococcus faecalis and Enterococcus faecium from teaching hospital in Malaysia. Infect Drug Resist. 2019;12:3269-74.

18. Daniel DS, Lee SM, Gan HM, Dykes GA, Rahman S. Genetic diversity of Enterococcus faecalis isolated from environmental, animal and clinical sources in Malaysia. J Infect Public Heal. 2017;10:617-23.

19. Wada Y, Harun A, Yean C, Zaidah A. Vancomycin-resistant Enterococcus: Issues in human health, animal health, resistant mechanisms and the Malaysian paradox. Adv Anim Vet Sci. 2019;7:1021-34.

20. Yip T, Tse K-C, Ng F, Hung I, Lam M-F, Tang S, et al. Clinical course and outcomes of single-organism Enterococcus peritonitis in peritoneal dialysis patients. Periton Dialysis Int. 2011;31:522-8.

21. Niek WK, Teh CSJ, Idris N, Thong KL, Ponnampalavanar S. Predominance of ST22-MRSA-IV clone and emergence of clones for methicillin-resistant Staphylococcus aureus clinical isolates collected from a tertiary teaching hospital over a two-year period. Jpn J Infect Dis. 2019;72:228-36.

22. Zarizal S, Yeo CC, Faizal GM, Chew CH, Zakaria ZA, Jamil Al-Obaidi MM, et al. Nasal colonisation, antimicrobial susceptibility and genotypic pattern of Staphylococcus aureus among agricultural biotechnology students in Besut, Terengganu, east coast of Malaysia. Trop Med Int Health. 2018:23:905-13.

23. Boswihi SS, Udo EE. Methicillin-resistant Staphylococcus aureus: An update on the epidemiology, treatment options and infection control. Curr Med Res Pract. 2018;8:18-24.

24. Sit PS, Teh CSJ, Idris N, Sam I-C, Syed Omar SF, Sulaiman H, et al. Prevalence of methicillin-resistant Staphylococcus aureus (MRSA) infection and the molecular characteristics of MRSA bacteraemia over a two-year period in a tertiary teaching hospital in Malaysia. BMC Infect Dis. 2017;17:274.

25. Aklilu E, Chia HY. First mecC and mecA positive livestock-associated methicillin resistant Staphylococcus aureus (mecC MRSA/LA-MRSA) from dairy cattle in Malaysia. Microorganisms. 2020;8:147.

26. Zhang S, Sun X, Chang W, Dai Y, Ma X. Systematic review and meta-analysis of the epidemiology of vancomycin-intermediate and heterogeneous vancomycin-intermediate Staphylococcus aureus isolates. PLOS ONE. 2015;10:e0136082.

27. Ahmad N, Ling LN, Ghani M, Nawi S. The presence of heterogeneous vancomycin-intermediate Staphylococcus aureus (heteroVISA) in a major Malaysian hospital. Med J Malaysia. 2012;67:269-73.

28. Ramli SR, Neoh H-M, Aziz MN, Hussin S. Screening and detection of heterogenous vancomycin intermediate Staphylococcus aureus in Hospital Kuala Lumpur Malaysia, using the glycopeptide resistance detection Etest and population analysis profiling. Infect Dis Rep. 2012;4:e20.

29. Che Hamzah AM, Yeo CC, Puah SM, Chua KH, Rahman NIA, Abdullah FH, et al. Tigecycline and inducible clindamycin resistance in clinical isolates of methicillin-resistant Staphylococcus aureus from Terengganu, Malaysia. J Med Microbiol. 2019;68:1299-305.

30. Spiliopoulou I, Petinaki E, Papandreou P, Dimitracopoulos G. erm(C) is the predominant genetic determinant for the expression of resistance to macrolides among methicillin-resistant Staphylococcus aureus clinical isolates in Greece. J Antimicrob Chemoth. 2004;53:814-7.

31. Mohd Rani FA, Rahman NI, Ismail S, Alattraqchi AG, Cleary DW, Clarke SC, et al. Acinetobacter spp. infections in Malaysia: a review of antimicrobial resistance trends, mechanisms and epidemiology. Front Microbiol. 2017:8:2479.

32. Mohd R, Nesam T, Kamaruzaman L, Cader RA, Mustafar R, Kong W-Y. Community acquired multi drug resistant (MDR) Acinetobacter baumannii pneumonia in Malaysia-a case report. Respir Med Case Rep. 2018;24:147-9.

33. Institute of Medical Research (IMR). National surveillance of antimicrobial resistance, Malaysia. Ministry of Health $(\mathrm{MOH})$, Kuala Lumpur, Malaysia. 2019. https://www.imr.gov.my/MyOHAR/index.php/site/archive_rpt. Accessed 4 Aug 2020.

34. Biglari S, Alfizah H, Ramliza R, Rahman MM. Molecular characterization of carbapenemase and cephalosporinase genes among clinical isolates of Acinetobacter baumannii in a tertiary medical centre in Malaysia. J Med Microbiol. 2015;64:53-8.
35. Kong BH, Hanifah YA, Yusof MYM, Thong KL. Antimicrobial susceptibility profiling and genomic diversity of multidrug-resistant Acinetobacter baumannii isolates from a teaching hospital in Malaysia. Jon J Infect Dis. 2011;64:337-40.

36. Fallah F, Noori M, Hashemi A, Goudarzi H, Karimi A, Erfanimanesh S, et al. Prevalence of bla $a_{\mathrm{NDM}}, b / a_{\mathrm{PER}}, b a_{\mathrm{VEB}}, b a_{\mathrm{IMP}}$, and bla $a_{\mathrm{VIM}}$ genes among Acinetobacter baumannii isolated from two hospitals of Tehran, Iran. Scientifica. 2014;2014:245162.

37. Naas T, Coignard B, Carbonne A, Blanckaert K, Bajolet O, Bernet C, et al. VEB-1 Extended-spectrum beta-lactamase-producing Acinetobacter baumannii. France Emerg Infect Dis. 2006;12:1214-22.

38. Naas T, Bogaerts P, Bauraing C, Degheldre Y, Glupczynski Y, Nordmann P. Emergence of PER and VEB extended-spectrum $\beta$-lactamases in Acinetobacter baumannii in Belgium. J Antimicrob Chemoth. 2006;58:178-82.

39. Thapa B, Tribuddharat C, Srifuengfung S, Dhiraputra C. Class 1 integron element in Thai Acinetobacter baumannii reveals a linkage to the European clone I. Int J Infect Microbiol. 2012;1:24-8.

40. Lean S-S, Suhaili Z, Ismail S, Rahman NIA, Othman N, Abdullah FH, et al. Prevalence and genetic characterization of carbapenem-and polymyxinresistant Acinetobacter baumannii isolated from a tertiary hospital in Terengganu, Malaysia. Int Sch Res Notices. 2014;2014:953417.

41. Cai Y, Chai D, Wang R, Liang B, Bai N. Colistin resistance of Acinetobacter baumannii: Clinical reports, mechanisms and antimicrobial strategies. J Antimicrob Chemoth. 2012;67:1607-15.

42. Hujer KM, Hujer AM, Hulten EA, Bajaksouzian S, Adams JM, Donskey CJ, et al. Analysis of antibiotic resistance genes in multidrug-resistant Acinetobacter sp. isolates from military and civilian patients treated at the Walter Reed Army Medical Center. Antimicrob Agents Ch. 2006;50:4114-23.

43. Sheikhalizadeh V, Hasani A, Ahangarzadeh Rezaee M, Rahmati-yamchi M, Hasani A, Ghotaslou R, et al. Comprehensive study to investigate the role of various aminoglycoside resistance mechanisms in clinical isolates of Acinetobacter baumannii. J Infect Chemother. 2017;23:74-9.

44. Hughes AJ, Ariffin N, Huat TL, Molok HA, Hashim S, Sarijo J, et al. Prevalence of nosocomial infection and antibiotic use at a University Medical Center in Malaysia. Infect Control Hosp Epidemiol. 2005;26:100-4.

45. Al-Kabsi AM, Yusof MYBM, Sekaran SD. Antimicrobial resistance pattern of clinical isolate of Pseudomonas aeruginosa in the University of Malaya Medical Center. Malaysia Afr J Microbiol Res. 2011;5:5266-72.

46. Fazlul M, Zaini M, Rashid M, Nazmul M. Antibiotic susceptibility profiles of clinical isolates of Pseudomonas aeruginosa from Selayang Hospital. Malaysia Biomed Res. 2011;22:263-6.

47. Idris S, Desa M, Aziz M, Taib N. Antimicrobial susceptibility pattern and distribution of exoU and exoS in clinical isolates of Pseudomonas aeruginosa at a Malaysian hospital. SE Asian J Trop Med. 2012;43:116-23.

48. Raja NS, Singh NN. Antimicrobial susceptibility pattern of clinical isolates of Pseudomonas aeruginosa in a tertiary care hospital. J Microbiol Immunol Infect. 2007:40:45-9.

49. Ho SE, Subramaniam G, Palasubramaniam S, Navaratnam P. Carbapenem-resistant Pseudomonas aeruginosa in Malaysia producing IMP-7 $\beta$-Lactamase. Antimicrob Agents Ch. 2002;46:3286-7.

50. Khosravi Y, Tay ST, Vadivelu J. Metallo- $\beta$-lactamase-producing imipenemresistant Pseudomonas aeruginosa clinical isolates in a university teaching hospital in Malaysia: Detection of IMP-7 and first identification of IMP-4, VIM-2, and VIM-11. Diagn Microbiol Infect Dis. 2010;67:294-6.

51. Khosravi Y, Tay ST, Vadivelu J. Analysis of integrons and associated gene cassettes of metallo- $\beta$-lactamase-positive Pseudomonas aeruginosa in Malaysia. J Med Microbiol. 2011;60:988-94.

52. Liew SM, Rajasekaram G, Puthucheary SD, Chua KH. Detection of VIM-2IMP-1- and NDM-1-producing multidrug-resistant Pseudomonas aeruginosa in Malaysia. J Glob Antimicrob Resist. 2018;13:271-3.

53. Rodríguez-Martínez J-M, Poirel L, Nordmann P. Extended-spectrum cephalosporinases in Pseudomonas aeruginosa. Antimicrob Agents Ch. 2009;53:1766-71.

54. Birgand G, Zahar J-R, Lucet J-C. Insight Into the complex epidemiology of multidrug-resistant Enterobacteriaceae. Clin Infect Dis. 2018;66:494-6.

55. Mobasseri G, Thong KL, Rajasekaram G, Teh CSJ. Molecular characterization of extended-spectrum $\beta$-lactamase-producing Klebsiella pneumoniae from a Malaysian hospital. Braz J Microbiol. 2020;51:189-95.

56. Ho WS, Balan G, Puthucheary S, Kong BH, Lim KT, Tan LK, et al. Prevalence and characterization of multidrug-resistant and extended-spectrum 
beta-lactamase-producing Escherichia coli from pediatric wards of a Malaysian hospital. Microb Drug Resist. 2012;18:408-16.

57. Khor S, Jegathesan M. Transferable antibiotic resistance in clinical isolates of Enterobacteriaceae in Malaysia. Med J Malaysia. 1983;38:19.

58. Al-Marzooq F, Mohd Yusof MY, Tay ST. Molecular analysis of antibiotic resistance determinants and plasmids in Malaysian isolates of multidrug resistant Klebsiella pneumoniae. PLoS ONE. 2015;10:e0133654.

59. Hsu L-Y, Apisarnthanarak A, Khan E, Suwantarat N, Ghafur A, Tambyah PA. Carbapenem-resistant Acinetobacter baumannii and Enterobacteriaceae in South and Southeast Asia. Clin Microbiol Rev. 2017;30:1-22.

60. Mohsen S, Hamzah H, Al-Deen MM. Phenotypic and molecular study of carbapenem-resistant Enterobacteriaceae in a referral hospital in the East coast Malaysia. Int J Health Allied Sci. 2018;7:17-22.

61. Zaidah AR, Mohammad NI, Suraiya S, Harun A. High burden of carbapenem-resistant Enterobacteriaceae (CRE) fecal carriage at a teaching hospital: Cost-effectiveness of screening in low-resource setting. Antimicrob Resist Infect Control. 2017;6:42.

62. Al-Marzooq F, Ngeow YF, Tay ST. Emergence of Klebsiella pneumoniae producing dual carbapenemases (NDM-1 and OXA-232) and 16S rRNA methylase $(\operatorname{armA})$ isolated from a Malaysian patient returning from India. Int J Antimicrob Ag. 2015;45:445-6.

63. Malchione MD, Torres LM, Hartley DM, Koch M, Goodman JL. Carbapenem and colistin resistance in Enterobacteriaceae in Southeast Asia: Review and mapping of emerging and overlapping challenges. Int J Antimicrob Ag. 2019;54:381-99.

64. Low Y-M, Yap PS-X, Abdul Jabar K, Ponnampalavanar S, Karunakaran R, Velayuthan $\mathrm{R}$, et al. The emergence of carbapenem resistant Klebsiella pneumoniae in Malaysia: correlation between microbiological trends with host characteristics and clinical factors. Antimicrob Resist Infect Control. 2017;6:5.

65. Bradford PA, Kazmierczak KM, Biedenbach DJ, Wise MG, Hackel M, Sahm DF. Colistin-resistant Enterobacteriaceae: correlation of $\beta$-lactamase production and colistin resistance among isolates from a global surveillance program. Antimicrob Agents Ch. 2015;60(3):1385-92.

66. Yap PSX, Ahmad Kamar A, Chong CW, Yap IKS, Thong KL, Choo YM, et al. Intestinal carriage of multidrug-resistant gram-negative bacteria in preterm-infants during hospitalization in neonatal intensive care unit (NICU). Pathog Glob Health. 2016;110:238-46.

67. Mobasseri G, Teh CSJ, Ooi PT, Thong KL. The emergence of colistinresistant Klebsiella pneumoniae strains from swine in Malaysia. J Glob Antimicrob Resist. 2019;17:227-32.

68. Hooper DC, Jacoby GA. Mechanisms of drug resistance: quinolone resistance. Ann NY Acad Sci. 2015;1354:12-31.

69. Al-Marzooq F, Mohd Yusof MY, Tay ST. Molecular analysis of ciprofloxacin resistance mechanisms in Malaysian ESBL-producing Klebsiella pneumoniae isolates and development of Mismatch Amplification Mutation Assays (MAMA) for rapid detection of gyrA and parC mutations. BioMed Res Int. 2014;2014:601630.

70. Thong KL, Ngoi ST, Chai LC, Teh CSJ. Quinolone resistance mechanisms among Salmonella enterica in Malaysia. Microb Drug Resist. 2016;22:259-72.

71. Kim HB, Park CH, Kim CJ, Kim E-C, Jacoby GA, Hooper DC. Prevalence of plasmid-mediated quinolone resistance determinants over a 9-year period. Antimicrob Agents Ch. 2009;53:639-45.

72. Hopkins KL, Davies RH, Threlfall EJ. Mechanisms of quinolone resistance in Escherichia coli and Salmonella: recent developments. Int J Antimicrob Ag. 2005;25:358-73.

73. Sirat R, Hamzah HA, Mahmud MIAM, Ahmad SNB. Molecular characterization of gyrA, parC and qepA genes in quinolone resistant ESBL-producing E. coli isolated from patients in HTAA, Kuantan. IIUM Med J Malaysia. 2019:18:2.

74. Correia S, Poeta P, Hébraud M, Capelo JL, Igrejas G. Mechanisms of quinolone action and resistance: where do we stand? J Med Microbiol. 2017;66:551-9.

\section{Publisher's Note}

Springer Nature remains neutral with regard to jurisdictional claims in published maps and institutional affiliations.
Ready to submit your research? Choose BMC and benefit from:

- fast, convenient online submission

- thorough peer review by experienced researchers in your field

- rapid publication on acceptance

- support for research data, including large and complex data types

- gold Open Access which fosters wider collaboration and increased citations

- maximum visibility for your research: over $100 \mathrm{M}$ website views per year

At BMC, research is always in progress.

Learn more biomedcentral.com/submissions 